\title{
Teaching Baltimore Together: building thematic cooperation between classes
}

Samuel Gerald Collins, Matthew Durington, and Nicole Fabricant

\begin{abstract}
One year ago, Baltimore citizens took to the streets to protest not only the death of Freddie Grey, but the structural inequalities and structural violence that systematically limit the opportunities for working-class African Americans in Baltimore. The protests, though, were not just confined to Baltimore City. Borne on sophisticated understandings of intersectionality and political economy, the moral imperatives from the Baltimore Uprising resonated with students at our university in Baltimore County, where campus activists moved to both support the people of Baltimore while using the moment of critical reflection to critique racial inequalities on campus. Since students were displaying a holistic, anthropological understanding of race and inequality in Baltimore, we decided to structure our classes accordingly and brought together several courses in the Department of Sociology, Anthropology and Criminal Justice in order to examine the interrelationships between power, race, class, public space and urban development. We taught common texts, visited each other's classes, and planned events that brought students together with community leaders in Baltimore to discuss common concerns and to learn from each other. This paper reports on that experiment and suggests that a pedagogical model premised on drawing thematic linkages between existing courses is one way to address current events that impact us all while allowing students to direct the course of their own education.
\end{abstract}

\section{Keywords}

Baltimore Uprising; community activism; campus activism; urban anthropology

\section{Introduction}

As more and more universities have institutionalized civic engagement into their organizational structure, curricula and student experience, opportunities for partnership between universities and surrounding communities have likewise multiplied. In particular, urban colleges and universities have led the field in initiating programs in multiple sites across U.S. cities. Of course, for many of us, these partnerships are not new and may be discipline-specific, although the institutional recognition of our community work as intrinsic to the mission of the university has been welcome. In particular, urban colleges and universities have led the way in emphasizing these linkages between their programs and numerous efforts underway throughout urban neighborhoods (Brown-Fraser et al., 2015; Watson-Thompson, 2015; Talmage et al, 2015). However, the other side of the civic engagement equation - one where the community precipitates changes in the university - has been less explored. In other words, while we celebrate the many ways universities have been able to "do good" in their communities, alternative possibilities that create change on the campus itself are also possible--and even desirable. After all, civic engagement develops the desire and the capacity of our students to 
intervene in their own communities, and their most immediate communities include our campuses. This possibility allows a space for a true reciprocity between the university and the community it wishes to serve. This case study describes our efforts, as three anthropologists at a state university just outside of Baltimore, to develop community programs that explore community groups as change agents for our campus through an emphasis on connecting community activism with campus activism and with progressive initiatives from campus administration.

\section{The Baltimore Uprising}

Home to numerous colleges and universities, Baltimore is simultaneously the site of hundreds of college-led civic engagement projects from community gardening to mural-painting. So much so that many of the private, smaller universities in the Baltimore region dedicate entire days to civic engagement where the student body en masse leaves the confines of the campus to go out into various communities. This often relies on scalability and institutionally based community engagement projects such as The United Way Project Homeless Connect where the goal is to serve thousands of citizens in one day through a resource fair with an equal number of volunteers to assist them. While these large-scale community engagement projects are commendable and provide students with a day of service, they are still unidirectional. It is the university via an institution acting upon the community providing a limited exposure to community issues. At the same time, numerous NPOs and NGOs in Baltimore work with diverse communities in the city on a range of issues. Many of these organizations are smaller and provide the opportunity for longer and sustained research based community engagement possibilities for both faculty and students. One is not necessarily valued over the other, they just provide different ways to create a conduit between the community and the university. Our argument is the latter provides more possibilities for the community to influence the type of engagement that occurs. That is, working with community activists with already active in their respective communities provides universities with pedagogically rich opportunities for engagement. On the other hand, going this route surrenders the terms of that engagement to community groups themselves. The community decides the type and means of university community engagement. In anthropology, this is what we strive for in collaboration; though interrogating power inequalities between university and communities, we invite interventions that gesture to alternative visions of community partnership.

The Baltimore Uprising - that is, the protests, demonstrations and police actions surrounding the death of Freddie Gray - was a pivotal event for the city. It was also pivotal for our university. Some area colleges sought to distance themselves from the unrest in Baltimore, emphasizing their geographical (and social) distance from the demonstrations. As a suburban university just 1.6 miles from the border of the Baltimore City, we were not "in" the demonstrations. But at the same time, our university was very much part of it, as an institution that had both historically contributed to the some of the structural problems that led to the Uprising (e.g., hypersegregation) as well as a comprehensive, state university with deep ties to Baltimore and to students who call Baltimore home. For most of us, what was happening in Baltimore was directly relevant to what we were doing. 
In response to the Uprising, faculty organized moderated conversations, teach-ins and other efforts to contextualize the Baltimore Uprising for the campus community. As they had for other world-changing events, faculty at our university sought to understand and to support both our students and the communities where we work through available channels of teaching and scholarship. While this put us one step closer to our students, particularly through a focus on social media, we realized that we also needed to recognize how students were connecting directly to the community and various social issues while circumventing the university structure. While social media allows the more nuanced and unfiltered access to social movements by faculty, it also provides a more direct channel of communication between students and activism. Other groups on the Towson University campus made these direct connections between the struggles in Baltimore and the campus. As the assemblage of activists organizing under the networked tag "\#BlackLivesMatter" took to the streets of Baltimore and many other cities around the world, students who had been organizing for change on campuses began to connect their own struggles to urban justice movements. That is, activism in cities across the United States not only inspired their support and participation, but it also stimulated a critical interrogation of the university as a site for both the reproduction of the status quo and an opportunity for resistance against that inequality. Through the fall semester of 2015, campus protests and occupations proliferated, accompanied by renewed demands for reform at every level of the university, from administration to the structure of promotion and tenure, to student life and campus policing (White, 2016). On our campus, students occupied the President's office for 8 hours before reviewing their demands, line by line, with our university's acting President (Campbell, 2015). In the end, they were recognized as one of the 'persons of the year' by Time Magazine (Wood, 2015). We viewed this negotiation between the administration and our students as a truly amazing moment of progressive engagement on our campus, and one where campus activists, faculty, staff and administration all seemed to speaking the same language.

The 13 demands our students presented are themselves indicative of the differences between this protest and other forms of student organizing. While much of the student activism over the last 20 years has been focused on specific interventions in the academy (e.g., introducing new curricula), the \#OccupyTowson demands span the entirety of the university; they amount to nothing less than a wholesale interrogation of the University's infrastructure, its governance, its raison-d'etre (Lemonik Arthur 2010). But more than this, the list connects issues of race, class and gender with urban struggles against oppression. In many ways, these activists are doing what we have advocated in our anthropology classes,i.e., moving between local and global issues across multiple contexts by resisting the compartmentalization of experience in silos of disciplinarity for a more holistic — and more critical — understanding (Turner 2016). Whereas some university administrators balked at student-led social movements and demands, leading to problematic consequences, Towson University has received accolades for adopting a more progressive approach that finds students, faculty and administrators continuing to work productively together (Chasmar, 2015). As of the spring of 2016, attentiveness continues to be directed at the list of demands created the previous year through a week-to-week analysis of the student newspaper on campus. In other words, the issue is not disappearing with graduating students. There is real momentum toward change. This is especially important for universities in urban metropolitan locales like Baltimore, where the legacies of the social unrest from 2015 have yet to be resolved. 
What people in Baltimore were demanding--and what students connected with those demands in their own campus activism were asking as well--was something more like a "right to the city," i.e., to live in a city that allows them to develop human and community potentials without pernicious race- and class-based inequalities. Indeed, a year after the Baltimore Uprising, activists were still confronting the city's systematic, structural inequalities. And while there are numerous,pressing injustices to be addressed, one of the most challenging questions we could ask people in power is simply that: where is the "right to the city" for the majority of Baltimore's residents? This does not mean the right to buy and consume in Baltimore's tourism spaces. Instead, it is about heretofore marginalized peoples "fighting for the kind of development that meets their needs and desires" (Harvey, 2013: xvi). And not just in the short term. As Henri Lefebvre wrote in the shadow of the Paris Commune, "To the extent that the contours of the future city can be outlined, it could be defined by imagining the reversal of the current situation, by pushing to its limits the converted image of the world upside down" (Lefebvre, 1996 [1967]: 172).

It is about imagining radical alternatives to the city, and, potentially, to the structure of the university. The intent is to re-forge it, in Robert Park's words, into "the heart's desire" for ordinary citizens, rather than for a handful of the wealthy and privileged. Similarly, is it possible for the university to be refashioned by students and communities expressing the same desires? This is the challenge for universities and, particularly for universities in Baltimore in the wake of the Baltimore Uprising. It is also a challenge for anthropology (our home discipline). Despite the growth of a public anthropology, the field still often divides into a theoretical concern with power and politics, on the one hand, and an applied anthropology that packages its portmanteau methods for sale, on the other. In public anthropology, critical interventions are oftentimes uncomfortably grafted onto traditional, descriptive research, a sometimes grudging admission that anthropology may contribute to the public weal. But how do we forge a pedagogy that not only invites students to reflect on these issues, but that also demands that they acknowledge the work already being accomplished by community groups?

\section{The Plan}

When we began discussions in the fall of 2015 about courses in the spring of 2016, the Baltimore Uprising and the \#OccupyTowson movement were foremost on our minds. Students who had not been active in either movement were struggling to make sense of the changing landscape, and we were eager to address their concerns in our classes. But how? On the one hand, we were loath to "co-opt" either of these social movements by representing them as something that our university (as an institution) had initiated; nor did we want to take anything away from the struggle and sacrifice of community leaders and activists. On the other hand, we could see in the political and social unrest real opportunities to link together people we've worked with over the years in Baltimore with our university. We were trying to avoid the usurping of the political and social moment by the institution as it so often occurs. Rather, we sought to speak alongside and not for or with our community collaborators. In fact, it suggested a moment when our university's metropolitan orientations seemed to align perfectly with urban issues in Baltimore--and it did so through the medium of our own students, who, mostly without our help, had recognized their own struggles in those of Baltimore communities. At the outset, then, we were taking cues from 
our students, who were making their own connections between university and city, between disciplines, between administration and faculty and, finally, between theory and practice.

The process was undertaken by the authors to unite syllabi, their courses and themselves throughout the academic year of 2015-2016 to address these issues. It would see students sharing ideas and research projects, faculty visiting and team-teaching their courses and the development of experiential opportunities connected to curriculum. We retooled our courses to incorporate common readings (David Harvey's Right to the City), and brainstormed about common activities that could unite three courses at a profound level. We didn't want our classes to simply cooperate together for a single event. This was to be a more profound collaboration on several levels. Not only were the courses complementary (a theory course, an urban anthropology course and a design anthropology course), but many of the same students were enrolled in each.

All of these efforts were coupled with direct support from the university administration and student services to assist these efforts. And, after consulting with our Office for Student Diversity, we decided upon the idea of a tour. But not without many reservations. For one thing, the idea of a "tour" of Baltimore's struggles is fraught with connotations of urban flaneurs and adventure tourism, and we did not want to add one more one-sided representation of Baltimore as the city of "The Wire" and "The Corner." Instead, we envisioned something along the lines of our previous collaborations with community groups in different parts of Baltimore (Collins \& Durington, 2014). Not, in other words, so much a "tour" as a series of pedagogical encounters with people, place and practice.

And, since we were positioning community groups in Baltimore as "teachers," we worked with our university to provide compensation for people's time, a practice that may raise ethical questions in research, but one that recognizes that people in our communities are our peers and, in the context of our work, deserve to be compensated as the professional they are. In our past experiences with our National Science Foundation Research Experience for Undergraduates project 'Anthropology by the Wire' (http://anthropologybythewire.com/), we witnessed the empowerment that occurs when community members are put into the role of 'educating' college students on their daily lives and larger structural issues.

Since the tour was to take place early in the semester, we had to organize it before students had arrived on campus. Drawing from our collaborative partners from our previous work in Baltimore, we engaged different community groups, including members of an anarchist collective coffee shop, students involved in protesting a planned incinerator in their neighborhood, an activist fighting gentrification led by another university in East Baltimore, and a housing activist fighting for fair trials for renters in the city. Each stop saw students pile off the bus after being challenged by our colleagues on the bus during their travels. While it was unavoidable to create the spectacle of an obvious student group entering a community, particularly when you are standing outside of rent court in Baltimore City, hindering traffic, it created a space of opportunity simultaneously. We were in the public, and the public responded in turn through curiosity and often joined in on the conversation.

We also decided to have a debriefing session after the tour that could help students to take what they'd witnessed in Baltimore and generate ideas for projects both in Baltimore and on their own 
campus. But since we were exposing students to the ways community groups can help create more democratic and more collaborative decision-making in urban development, we wanted to model those collaborative processes by challenging our students to plan the de-briefing panel. We only provided the venue: an open event space in an old church that was operated by a cooperative. Over the first two months of the Spring 2016 semester, students debated what they wanted to accomplish, whom to invite, and the format a discussion could take. How would they accomplish this formidable task, setting an agenda for not only their own work in the community, but for the university to pursue as it explores its responsibilities to Baltimore?

Students ultimately decided on a range of community and campus organizers they thought would generate critical dialogue capable of interrogating the artificial separation of our university from the city around it. These included the leader of a community art center in West Baltimore, high school students who had worked to defeat an incinerator in their South Baltimore, a long-time member of a farming collective from North Baltimore, and one of the student leaders who had led her colleagues in the \#OccupyTowson movement on campus. They opted for brief introductions from all of the panelists, followed by question and answer with accompanying discussion. Over February and March, they debated the format for the panel discussion, went back and forth with the participants they'd invited, and prepared flyers, posters and blog posts advertising the discussion.

\section{The Courses}

As noted, there was a concerted effort by the authors to imbue their courses with similar materials and a curricular orientation that would allow students to create research based community engagement and imagine a number of different projects. Students were given the opportunity to blend writing assignments in the three different courses, collaborate across courses on projects and design materials together. While this took an extra amount of work on the part of the faculty, once the students recognized that their professors were stepping up to create these possibilities, they responded with zeal. And, through the shared reading on The Right to the City (Harvey, 2013) they were able to apply this central concept to their various endeavors. The first course, Anthropological Theory, is a writing intensive capstone course for anthropology majors. Students utilized the thematic for the semester to develop a theoretical orientation to applied urban anthropological research. For the Design Anthropology course elements of publicity were created by students with a thoughtfulness toward reaching not only the larger student body, but also citizens in Baltimore. Students were also given the opportunity to literally 'design' an urban-based research project. Finally, our urban anthropology course 'Life in the City' provided students with a comprehensive survey of literature in the field that they could then apply for review and application to their research projects. Evaluations for all three courses demonstrated the impact the thematic had on students. Additionally, we as faculty have imagined new possibilities for curriculum in our concentration while students have a more enhanced idea of how their various courses in anthropology inform one another.

\section{The Tour}


We had worried for weeks about buses. Tour buses, we believed, were exactly the wrong image we wanted to project. Of course, we were tourists of a sort, but "tourism" implies an inequality and a level of commodification that represented the exact antithesis of what we wanted to do. Luckily, though, our Center for Student Diversity had contracted out school buses for us instead, and we proceeded to Baltimore neighborhoods as students. After all, we were there to learn from community activists. The tour would not have the university emblazoned vehicle descending on the community signaling voyeurism and a tour led by an outsider. Rather, two old yellow school buses, the universal sign of a set of individuals journeying to a destination of learning, would take students to the city with two community activists outside of the university leading the way and challenging everyone throughout the entire journey.

The first stop was at Baltimore's Federal Hill, a park overlooking the Inner Harbor, the model of Baltimore post-industrial development policies and simultaneously the source of its growing inequality between, for example, highly-paid labor in finance, medicine and education and service workers unable to earn a living wage. It is also the site of one of the most informative urban musings on the City of Baltimore from David Harvey, A View From Federal Hill, that we utilized in our courses as a precursor to discussions of the right to the city (Harvey, 2013). After that, we moved to Curtis Bay, a neighborhood in the middle of Baltimore's industrial hub, and one subject to severe, environmental pollution. Despite this, Free Your Voice, a group of mostly high school students living in the neighborhood, continue to fight for positive changes in the neighborhood, including efforts to reduce pollutants. From there, we continued into downtown Baltimore, where we met with the Right to Housing Alliance, a group that lobbies for fair housing in the City and assists residents in their efforts to fight unfair housing practices. After that, we moved up the road into East Baltimore, where Marisela Gomez, a local activist in housing and public health, outlined the course of ruinous development policies in East Baltimore, and the efforts of people and groups in the community to ameliorate those inequalities (Gomez, 2013). Finally, the group finished the tour at Red Emma's, a coffeehouse cooperative that anchors the artist community in South Charles Village, where members of the Red Emma's collective addressed alternatives to top-down development and gentrification.

\section{Feedback}

Students produced field notes on various platforms in the wake of the tour. Their comments suggest the complexity of both the events they planned and student reactions. Most noted the heterogeneity of community activists and projects. Some, students pointed out, actively resisted a status quo defined by Baltimore's developmental imperatives, while others partnered with government in order to affect change. And yet, there were also threads of continuity. All of the groups worked to ameliorate problems experienced by Baltimore residents in the wake of shifts in political economy and demographics over the past 50 years. All of the groups, whether working to stem runaway development or stop an incinerator from polluting an already distressed neighborhood, called into question Baltimore's development strategies, specifically the "eds and meds" style of development embraced by many post-industrial cities in the United States. Given the extent of disenfranchisement in many of the neighborhoods students visited, 
they wondered about the possibility of resisting the "city-as-growth" machine, especially for people without access to both social and material capital (Logan \& Molotch, 1987).

Students produced field notes on various platforms in the wake of the tour. These suggest the complexity of both the events they planned and student reactions. These questions shaped the follow-up panel discussion after the tour. This panel was strategically located off-campus to both bring our students further out of the university confines and meet our interlocutors in their own city. A number of questions guided this public presentation and panel. What does it mean to "really" collaborate with community partners? Can college students be allies to grassroots community activism without co-opting a struggle for their own self-aggrandizement? In other words, can students facilitate the right to the city? How? And what about the problems of race, inequality and intolerance on our own campus?

The questions students took with them into the panel discussion were ones that directly sought to bridge the activism they'd seen on their tour with their own commitments to social change and their postgraduate plans. It was strategic that students develop these questions prior to the event so that they were well thought out and related directly to their research projects in individual courses, and they vetted their questions with us and with the class. The pivotal moment of the evening was with one of their colleagues at the university. An activist and student named Bilphena Yahwon had been part of \#OccupyTowson and urged attendees to both understand "intersectionality and oppression on different levels" and to "make academics accessible and relatable to people and communities" (Yahwon 2016). Her message: be an ally to these urban, social movements by working to support the activists on your own campus. And, if you have friends that are unaware of issues around race, class and what is happening in Baltimore, educate them first as an ally. While we would like to think we garner respect from our students in our classrooms, we know that hearing from one of their colleagues and witnessing her concerted efforts to unite her studies, activism and identity was highly impactful. By far, this moment, where the students heard from their own, provided the epiphany where they were able to realize that they too could embody and enhance the activism they were witnessing all around them both in the city and on campus.

\section{Outcomes}

We have documented student-level, program-level and university-level outcomes from our program. The most striking outcomes have been with our students, who have modeled the work of community activists within the scope of their own activism and career aspirations. We have witnessed students engage activism on campus and in the city as well as developing thesis and independent study projects ranging from analyses of lead-paint poisoning in Baltimore to engaged work with local high school students on other issues of environmental justice.

Simultaneously, we were fortunate enough to have an editor for the student newspaper as one of our majors who also wrote an article after the tour to highlight what students were able to garner from the experience. Students from the collective courses have also gone on to create a student activist group (that emphasizes the linking of allies to the \#OccupyTowson and \#BlackLivesMatter groups on campus) called W.A.R.S. (White Allies for Radical Solidarity). This latter development provides a space of pragmatic solidarity and diversity to be enhanced 
among student groups interested in these topics and combining their research endeavors with activism.

We have taken lessons learned from the thematic to create a renewed emphasis on curricular reform that focuses on topics of race and the urban for Towson University's 'metropolitan' core category. Faculty have also become involved with a larger faculty/student/staff/administration group on campus formed around social justice initiatives broadly. This social justice "collective" has allowed us to plan larger initiatives, including a planned cooperative project around environmental justice (see below) that will span the university. The collective has also allowed us to begin to formulate larger, curricular transformations that build in engagements with community activists to the courses we offer our students.

On the community side, the project has generated considerable good will with concrete consequences. Universities in Baltimore have (fairly or not) often been accused of swooping down on neighborhoods for abbreviated "performances" of civic engagement without followthrough: photos may appear on websites and in alumni magazines, but projects are not sustained, and relationships may rarely outlast the tenure of the staff in charge of civic engagement initiatives. But our approach is much more humble: we come to learn and to support the work communities are already doing. We have sustained our involvement in communities through additional programs, through grant writing and through supporting young people in communities through the college application process. We believe that initiatives like this build a different image of our university as a place where people try to help each other learn rather than a place where learning is dispensed.

Finally, we have been quite pleased to see university administrators formulate high-level goals, which are usually expressed as outcomes of programs that are either still in process or, more frequently, that have not yet been implemented. All entities are making a concerted effort to meet our students where they are and also guide them toward an orientation that sees the community driving and influencing the types of engagement that occurs from the university writ large. They have been generous with funding for next year, and have, moreover, worked towards structuring more permanent relationships with community activists through a variety of MOUs (Memoranda of Understanding).

\section{The Next Project}

In the wake of last year's successes, we met over the summer with staff and administration to plan for this year. During Spring of 2017, we will again tie together different courses around common themes, experiences and engagements with Baltimore communities and activists, this time around the theme of environmental justice. With even more support from staff and administration, we are expanding to 10 faculty across 7 departments including the arts, sciences, health and the liberal arts. In order to accommodate larger numbers of students and their different schedules, we will have 3 tours spread out over 2 weeks, with a large briefing session before and a series of de-briefs afterwards. This will be the largest effort at our university (that we know of) to bring together students, faculty and staff around a common civic engagement theme. 
Whatever happens, we will strive to sustain this student and faculty-driven engagement at our university, cognizant that it will no doubt change with shifts in staff and institutional priority.

\section{Conclusion}

This thematic experiment also provides us an opportunity to reflect on the notion of engagement by our university (and what model may be best for other universities) to create these opportunities for students, faculty and those they desire to work with collaboratively. Like many of the institutions that subscribe to this journal, Towson University is a member of the Coalition of Metropolitan and Urban Universities. Also, like many institutions near or in urban spaces nationally, Towson University underwent the Carnegie classification process several years ago to be classified as a 'Metropolitan University'. The metropolitan university has since been eliminated from the Carnegie classification model and an 'Elective Community Engagement Classification' has been created. Towson University is currently one of the institutions that has gone through the process to be classified in this fashion as of 2015. In following the guidelines for this classification strata, Towson has made a commitment to fulfill the following mandate:

"Community engagement describes collaboration between institutions of higher education and their larger communities (local, regional/state, national, global) for the mutually beneficial exchange of knowledge and resources in a context of partnership and reciprocity. The purpose of community engagement is the partnership of college and university knowledge and resources with those of the public and private sectors to enrich scholarship, research, and creative activity; enhance curriculum, teaching and learning; prepare educated, engaged citizens; strengthen democratic values and civic responsibility; address critical societal issues; and contribute to the public good."

(http://nerche.org/index.php?option=com_content\&view=article\&id=341\&Itemid=618)

While Towson has a strong civic engagement and student volunteer mechanism, the university is continually striving to model curriculum that fulfills the entirety of this mandate, particularly in the attempt to connect 'research' and 'civic' responsibility. The model that has been developed in this thematic experiment links faculty research, scholarship, curriculum and civic responsibility. What it also offers is a means to 'address critical societal issues' in a timely manner, while simultaneously creating a process for all of these factors to be driven by the community and students, more so than faculty. This reversal of the traditional process creates a different mode of agency where the guiding force is the community and students more so than the faculty and university. This provides an opening for a more enhanced mode of research based community engagement that might provide a space for volunteerism and civic engagement but goes much further. It demonstrates that there is also a space for much-needed advocacy on the part of the university, to stand alongside our community collaborators in a space of empathy that confronts dynamics of power. We believe this is a model for a reversal of the usual process of civic and community partnership.

We offer the following guidelines for the possible implementation of similar projects amongst our colleagues: 
1. We need to emphasize that the city and the university are intimately inter-related, that what happens in cities is simultaneously happening on your university, and that what we do on campus can - and should - address the problems of the urban milieu.

2. Faculty bear the responsibility of linking together the agendas of our institution with those of our students. Sometimes these agendas can diverge, but sometimes faculty can help to facilitate agreement.

3. Faculty also need to step outside of their departments to enjoin not only other faculty, but staff and administration. Doing so means inevitable shifts in the tenor of the original program, but also means that this will be a university effort with a strong interdisciplinary orientation.

4. Networking between communities and universities can generate powerful educational experiences that can act as both opportunities and models for student involvement.

5. Learning is more powerful when it's compounded across both courses and the college experience. Students learn by through integrated systems of practice.

\section{Acknowledgements}

These curricular experiments were supported at every level of our university, but we would like to give special thanks to Towson University's Center for Student Diversity, the Office of the Provost, the Office of Student Engagement, the College of Liberal Arts and the Department of Sociology, Anthropology and Criminal Justice. Thanks also to our community partners in Baltimore, and to Towson University Marketing and Communications for documenting our journey in photographs.

\section{References}

Campbell, C. (2015). Towson U. President signs students' demands after 8-hour protest in his office. Baltimore Sun 11/19/2015. Retrieved from http://www.baltimoresun.com

Chasmar, J. (2015). Towson University President signs black students' demands after an 8-Hour protest in his office. Washington Post. Retrieved from http://www.washingtontimes.com

Collins, S.G. \& Durington, M.S. (2014). Networked Anthropology. New York, NY: Routledge.

Gomez, M. B. (2013). Race, class, power, and organizing in East Baltimore. Lanham, MD: Lexington Books.

Harvey, D. (2013). Rebel cities. New York, NY: Verso.

LeFebvre, H. (1996[1967]). Writings on cities. Cambridge, MA: Wiley-Blackwell.

Leminik Arthur, M. (2010). Student activism and curricular change in higher education. Burlington, VT: Ashgate. 
Logan, J. \&. Molotch H. L. (1987). Urban fortunes. Berkeley, CA: University of California Press.

Talmage, C., Dombrowski, R., Pstross, M., Peterson, C. B. and Knopf, R.C. (2015). Discovering diversity downtown: Questioning Phoenix. Metropolitan Universities 26(1): 113-146. Retrieved from https://journals.iupui.edu/index.php/muj/article/view/20991

Turner, D. (2016). How black students are saving higher education. Journal of Critical Scholarship on Higher Education and Student Affairs 2(3), 6-7.

Watson-Thompson, J. (2015). Exploring community-engaged scholarship as an intervention to change and improve communities. Metropolitan Universities 26(1), 11-34. Retrieved from https://journals.iupui.edu/index.php/muj/article/view/20986

White, K. (2016). Black lives on campus matter. Soundings 63, 86-97. https://doi.org/10.3898/136266216819377002

Wood, Pamela (2015). Towson activists, photographer Devin Allen honored in TIME Magazine 'Person of the Year' issue" Retrieved from http://www.baltimoresun.com.

Yahwon, Bilphena (2016). Remarks delivered at "Shaping the City: Diverse Perspectives on the Right to the City," April 1, 2016. Baltimore, Maryland. 


\section{Author Information}

Samuel Gerald Collins is an anthropologist at Towson University in Baltimore, Maryland. His present work examines the urban as the confluence of people and social media, and looks to intervene in strengthening the ability of communities in cities to represent themselves. He is the author of All Tomorrow's Culture: Anthropological Engagements with the Future (2008), Library of Walls (2009) and, along with co-author Matthew Durington, Networked Anthropology (2014).

Samuel Gerald Collins

Dept. of Sociology, Anthropology and Criminal Justice

Towson University

Towson, MD 21252

Email: scollins@ towson.edu

Telephone: 410-704-3199

Matthew Durington is professor of anthropology at Towson University. He is the co-author of Networked Anthropology (Routledge 2014) with Samuel Collins. His current ethnographic research focuses on housing, race and media methodologies in Baltimore and Southern Africa.

Matthew Durington

Dept. of Sociology, Anthropology and Criminal Justice

Director of International Studies

Towson University

Towson, MD 21252

Email: mdurington@ towson.edu

Telephone: 410-704-5256

Nicole Fabricant is an associate professor of anthropology at Towson University. She is the author of Mobilizing Bolivia's Displaced: Indigenous Politics and the Struggle over Land (UNC Press 2012) and co-editor of Remapping Bolivia: Resources, Territory, and Indigeneity in a Plurinational State (School for Advanced Research Global Indigenous Politics Series 2011). Her current ethnographic work focuses on the history of toxicity in Curtis Bay, Maryland and youth movements fighting for environmental justice.

Nicole Fabricant

Associate Professor of Anthropology

Towson University

8000 York Road

Towson, MD 21252

Liberal Arts Building 3355

Email: nfabricant@towson.edu

Telephone: 410-704-5221

www.nicolefabricant.com 